\title{
Somatic embryogenesis and plant regeneration from cell suspension cultures of Gentiana kurroo Royle.
}

Shiwani Kaushal ${ }^{1,2 *}$ and Arushdeep Sidana ${ }^{1}$

${ }^{1}$ Department of Biotechnology, Shoolini University, Solan, Himachal Pradesh, 173229, India.

2Department of Biosciences, Asian Educational Institute, Patiala, Punjab 147001, India.

Received: 4/10/2018; Revised: 4/20/2018; Accepted: 4/27/2018

\begin{abstract}
Gentiana kurroo Royle, native to North- Western Himalayas, is one of the critically endangered perennial herbs, which is being overexploited due to its multiple medicinal uses. The goal of this work was to develop a protocol for somatic embryogenesis and efficient plant regeneration through cell suspension culture. Selected ranges of plant growth regulators were experimented for somatic embryogenesis. Light micrographs of the established suspension cell cultures of somatic embryos at different developmental stages were also observed under light microscope. Somatic embryogenesis was induced from the leaf explants and the maximum induction frequency $(97.2 \%)$ was obtained on Murashige and Skoog (MS) medium supplemented with $0.5 \mathrm{mg} / \mathrm{l}$ each of NAA, BAP and TDZ. Cell suspension cultures were established in MS liquid medium containing IAA $(0.5 \mathrm{mg} / \mathrm{l})+$ BAP $(1.0 \mathrm{mg} / \mathrm{l})$ with $89-93 \%$ viable cells. Transfer of cotyledonary somatic embryos to the MS agar medium containing 2, 4-D (0.4 mg/l) and $\mathrm{KN}(1.5 \mathrm{mg} / \mathrm{l})$ resulted in somatic embryogenesis at high frequencies $(80 \%)$ with an average of $28 \pm 0.2$ embryos/ callus piece. After transfer onto the half strength MS medium without growth regulators approximately $80-90 \%$ somatic embryos developed into complete plantlets. The protocol described here could be used for somatic hybridization, genetic transformation, isolation of protoplasts and large-scale propagation of G. kurroo.
\end{abstract}

Keywords: Cell suspension, Gentiana kurroo, Murashige and Skoog (MS), Somatic embryogenesis

\section{Introduction}

Gentiana kurroo Royle (Family: Gentianaceae) is an important native Indian species used for medicinal purposes. It is a rosette forming small perennial herb also known as Indian Gentian, Neelkanth, karu and chireta. It is mainly found in Kashmir and Himachal Pradesh with adjoining hills of North-Western Himalayas at altitudes of 1500-3400 m. In traditional and modern medicine, roots and rhizomes of this plant are valued as a bitter tonic, antiperiodic, antibilious, anthelmintic, astringent, antipsychotic, sedative, stomachic and carminative. The roots of this plant are a source of iridoid glycosides like gentiopicrine and gentiamarin and the alkaloid, gentianin (Raina et al., 2003). Unfortunately, the pharmaceutical industries are largely dependent on natural population of $G$. kurroo to fulfill their demands, which is depleting the wild stands of this plant. Therefore, this plant has been listed as critically endangered by the Government of India (Sharma et al., 1993). Many in vitro studies have been carried out on propagation of G. kurroo using shoot tips, nodal segments, seedlings, petioles, leaves and apical meristem as explants (Sharma et al., 1993; Fiuk et al., 2003; Sharma et al., 2014; Kaushal et al., 2014). It was found that $G$. kurroo can be propagated through rhizome cuttings; shoot nodal segments, seeds and somatic embryogenesis. Suspension culture studies have been previously established from seedling explants for various Gentiana species such as

*Corresponding Author:

Shiwani Kaushal,

Assistant Professor,

Department of Biosciences, Asian Educational Institute, Patiala, Punjab, India.

E-mail: shiwanikaushal23@gmail.com
G. tibetica, G. cruciata and G. pannonica (Mikuła and Rybczynski, 2001; Mikuła et al., 2005). Up to the present study very few workers have established the suspension cultures with the use of embryogenic callus derived from seedling explants (Fiuk and Rybczynski, 2008 a). Hence, in the present study, we have described the light micrographs showing stages in embryo development of G. kurroo Royle suspensions and plant regeneration through cell suspension cultures.

\section{Materials and Methods}

Plant Material

Two-week-old authentic aseptic cultures of Gentiana kurroo were collected from Dr. Y.S. Parmar University of Horticulture and Forestry, Nauni, Solan and was maintained under controlled temperature $\left(25^{\circ} \mathrm{C}\right)$, humidity $(70-75 \%)$ and light $(10$ $\mathrm{h}$ dark and $14 \mathrm{~h}$ light) conditions in a growth chamber.

\section{Culture media and growth conditions}

For initiating the tissue culture, leaf cuttings were used as explants for somatic embryogenesis. MS medium (Murashige and Skoog, 1962) containing 3\% sucrose gelled with $0.8 \%$ agar supplemented with varying concentrations and combinations of $\mathrm{BAP}$ (0.5-1.0 mg/l), TDZ (0.5-1.0 mg/l), NAA (0.5-1.0 $\mathrm{mg} / \mathrm{l})$ and 2 , 4-D (0.5-2.0 mg/l) were used as shown 
in the Table 1. The $\mathrm{pH}$ of the medium for somatic embryogenesis and suspension culture was adjusted to $5.8 \pm 0.1$ and $5.3 \pm 0.2$ respectively and was autoclaved at $121^{\circ} \mathrm{C}$ and $1.05 \mathrm{Kg} \mathrm{cm}^{-2}$ for $15 \mathrm{~min}$. The cultures were incubated at $16 \mathrm{~h}$ photoperiod provided by cool white fluorescent light (3,000 lux) at $25^{\circ} \mathrm{C}$ in a plant tissue culture chamber.

\section{Initiation and establishment of suspension cultures}

Cell suspensions were initiated by inoculating the friable callus into liquid medium. Individual cells or cell aggregates were maintained in suspension by agitation or aeration (Five replicates). Pieces of friable callus of approximately two-gram weight were removed from the petridishes and transferred into $250 \mathrm{ml}$ conical flasks containing $50 \mathrm{ml}$ of culture medium. The culture flasks were sealed with two layers of aluminium foil and paraflim. Cultures initiated from friable callus and embryogenic callus were incubated in the dark and $16 \mathrm{~h}$ photoperiod respectively on a rotary shaker at 110 r.p.m. at $25 \pm$ $1^{\circ} \mathrm{C}$.

Subculture and maintenance of cell suspensions The first subculture was performed 10 days after initiation of the culture. The suspended cells were filtered through a double layer of $250 \mu \mathrm{m}$ nylon meshe into a $100 \mathrm{ml}$ measuring cylinder and allowed to settle down for 5-10 minutes. The supernatant was poured off and the cells were sub-cultured into a 250 $\mathrm{ml}$ conical flask containing $50 \mathrm{ml}$ of fresh medium. After incubation for 10 days on a rotary shaker at 110 r.p.m. at $25 \pm 1^{\circ} \mathrm{C}$, the cell suspension was again filtered through a double layer of nylon mesh. At this time, only $15 \mathrm{ml}$ of filtrate was used as inoculum for every $50 \mathrm{ml}$ of fresh medium. Subsequent subcultures were made at 7-day intervals and were incubated in the same way. Light micrographs showing stages in embryo development of G. kurroo Royle suspensions were developed. For plant regeneration, large embryogenic masses were eliminated from cell suspension and were transferred to the MS medium supplemented with different concentrations of BAP (1.0-3.0 mg/l), KN (1.0-3.0 $\mathrm{mg} / \mathrm{l})$, NAA (0.5-2.0 mg/l), 2, 4-D (1.0-2.0 mg/l) and IAA $(0.5-2.0 \mathrm{mg} / \mathrm{l})$.

\section{Statistical analysis}

The data for the percentage of somatic embryogenesis, initiation time, and number of embryos per explants, regeneration frequency of suspension culture and the average number of shoots/explants were determined after 6 weeks of subculture. Twelve replicates were tested in each treatment and each experiment was repeated thrice. Means and standard errors were calculated for each experiment. The overall variation in a set of data was analyzed by one way analysis of variance (ANOVA). $A$ value of $\mathrm{P}<0.05$ was considered significant.

\section{Results and Discussion}

\section{Somatic embryogenesis}

Many factors including choice of explants and suitable combination of growth regulators are responsible for successful somatic embryogenesis. Induction of somatic embryogenesis directly from leaf without undergoing callus induction was tried on MS medium with various concentrations of 2, 4- D (0.5- $1.5 \mathrm{mg} / \mathrm{l})$, BAP (0.25- $0.8 \mathrm{mg} / \mathrm{l})$, NAA (0.5- 1.0 $\mathrm{mg} / \mathrm{l})$ and TDZ (0.25- $0.8 \mathrm{mg} / \mathrm{l}$ ) (Table 1$)$. When the leaves were cultured on MS medium supplemented with various concentrations of TDZ, NAA and BAP (0.2-1.0 mg/l), somatic embryogenesis was initiated in about 8-12 days followed by rapid growth. Of the various concentrations of TDZ tested, the maximum response was observed on MS medium supplemented with $0.5 \mathrm{mg} / 1 \mathrm{NAA}, \mathrm{BAP}$ and TDZ where maximum percentage of embryogenesis was recorded as $97.2 \%$ (Table 1 ) and (Fig.1a-f). It has been reported that TDZ has a cytokinin and auxin like activity for promoting cell division, differentiation and somatic embryogenesis (Aboshama, 2011). Greenish globular embryos were produced from the explants after 6 weeks of incubation in continuous light. The globular embryos started further development in subsequent days. The embryos were soft, friable and organogenic in all concentrations of TDZ which further developed into heart and torpedo shaped after 3 weeks of subculture (Fig. $1 \mathrm{~g}, \mathrm{~h}$ ). A similar study was reported in G. kurroo, where the best morphological quality of embryos was observed in the presence of $2.0 \mathrm{mg} / 1$ NAA with $2.0 \mathrm{mg} / 1$ each of TDZ or BAP in which highest frequency of embryogenesis was $54.7 \%$ which has been increased in our present study ((Fiuk and Rybczynski, 2008 b). Also, the concentration used in their study, was very high as compared to the concentration used in our study. This variation in $G$. kurroo response might be due to the difference in the genotypes and difference in the physiological state of the explants used in the two studies. 2, 4-D (0.8 $\mathrm{mg} / \mathrm{l})$ in combination with $0.8 \mathrm{mg} / \mathrm{l}$ each of BAP and TDZ was also effective in inducing somatic embryogenesis up to $83.3 \%$ (Table. 1). 2, 4- D in combination with cytokinins for inducing somatic embryogenesis have been reported in many plant species such as Bacopa monnieri and Curculigo orchioides (Tiwari et al., 1998; Nagesh et al., 2010).

Characterization and optimization of suspension culture medium

Optimum subculture regimes, culture conditions and concentrations of the different media components were evaluated in pre-experiments. A total of ten combinations of the suspension induction medium components listed in Table 2 were assessed in combination with the MS-macro and micronutrients. Five flasks with liquid medium were placed on shaker for cell suspension studies at $110 \mathrm{rpm}\left(25 \pm 2^{\circ} \mathrm{C}\right)$. For suspension culture, somatic embryos induced on $0.5 \mathrm{mg} / 1$ each of NAA, BAP and TDZ were 
transferred to the MS liquid medium containing IAA $(0.5 \mathrm{mg} / \mathrm{l})+\mathrm{BAP}(1.0 \mathrm{mg} / \mathrm{l})$ for agitation on a rotary shaker at $100 \mathrm{rpm}$ (Fig. 2 a-c). Previously reported studies have established auxin-cytokinin combination for somatic embryo formation in Gentiana species (Mikuła et al., 1996; Bach and Pawłowska, 2003). Embryogenic cell clumps were filtered through stainless sieves for uniform size. Suspension cultures were subcultured in the same medium after 7 days. The cell suspension was found to consist of small, round isolated cells with dense cytoplasm, an apparent nucleus, and rich in plastids with starch (Fig. 2 d, e). A few days after culture, 89$93 \%$ of the cells released were viable as assessed by cell counting method using erythrosine B stain. Average numbers of viable cells per square of haemocytometer were 10-11 and concentration of viable cell/ $\mathrm{ml}$ was $2.20 \times 10^{5}$ cells $/ \mathrm{ml}$ which is an optimum concentration to grow single cells. Previous suspension studies with G. kurroo were performed with the use of embryogenic callus derived from seedling explants (Fiuk and Rybczynski, 2007).

\section{Microscopic analysis}

Established cell suspensions of somatic embryos at different developmental stages were observed under light microscope. The embryos developed from single cells, which by unequal divisions formed two, four and eight celled stage (Fig. 3 a-c). After that, it formed a globular structure also known as a young embryo (Fig. 3 d). A young embryo by unequal divisions gave rise to a large mass i.e. proembryogenic mass or late proembryo stage (Fig 3. e, f). Further differentiation of proembryogenic mass led to the formation of early and late heart shaped embryos and finally to the cotyledonary stage with prominent shoot apices (Fig. $3 \mathrm{~g}$-1). In the earlier report of cell suspension culture of G. kurroo, authors observed the ultrastructure of G. kurroo, indicating the presence of amyloplasts and starch grains (Fiuk and Rybczynski, 2008 a). In their study, the best qualities of embryos were observed in the presence of $0.5-1.0 \mathrm{mg} / 1 \mathrm{KN}, 0.5 \mathrm{mg} / 1 \mathrm{GA}_{3}$ and $80.0 \mathrm{mg} / \mathrm{l}$ AS. Flow cytometry analysis revealed $100 \%$ uniformity for cotyledon suspensions with increased amounts of DNA in about one third of the regenerants. Serial stages in embryo formation by an isolated single cell from tissue culture of G. kurroo were also observed. Cell first divided by an unequal division forming a large vacuolated cell and small richly cytoplasmic cell, which, by a series of divisions gave rise to a tissue mass from which embryos were, differentiated (Fig. 4 a-e).

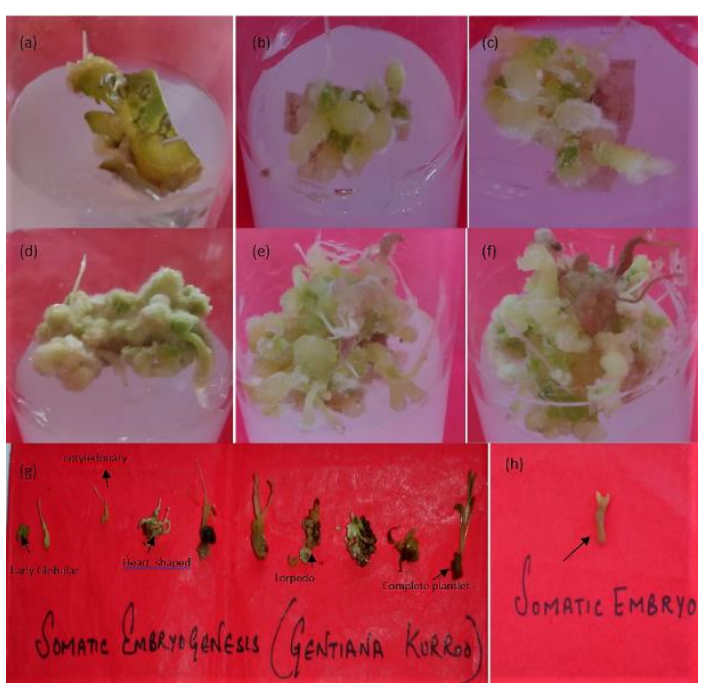

Fig. 1. Direct somatic embryogenesis of G. kurroo: (a) \& (b) Establishment of somatic embryogenesis from the leaf explant on MS medium supplemented with $0.5 \mathrm{mg} / 1$ each of BAP, NAA and TDZ after $8^{\text {th }}$ and $20^{\text {th }}$ day of inoculation; (c) \& (d) somatic embryo proliferation after $35^{\text {th }}$ and $45^{\text {th }}$ day; (e) \& (f) fully differentiated somatic embryos after $50^{\text {th }}$ and $60^{\text {th }}$ day of inoculation; stages of somatic embryo: (g) early globular, cotyledonary, heart and torpedo stages of somatic embryo; (h) somatic embryo.

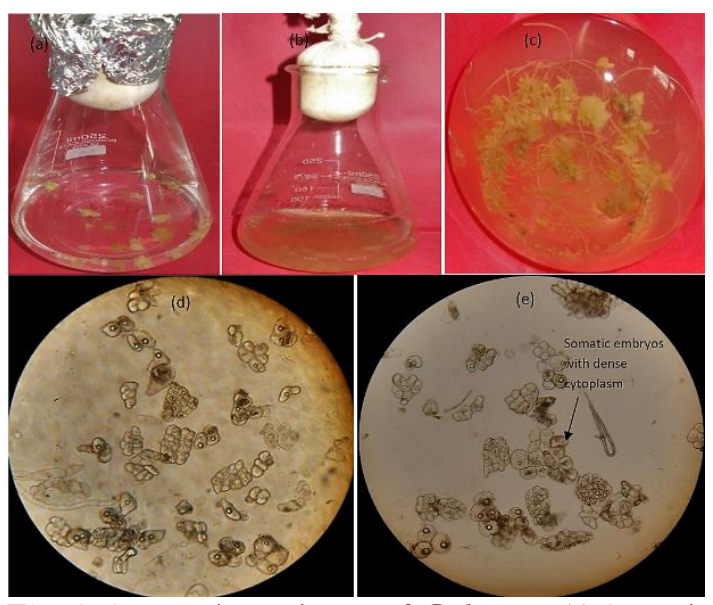

Fig. 2. Suspension cultures of G. kurroo: (a) Somatic embryos transferred to MS liquid medium containing IAA $(0.5 \mathrm{mg} / \mathrm{l})$ and BAP $(1.0 \mathrm{mg} / \mathrm{l})$; (b) \& (c) somatic embryo suspension cultures after 10 and 20 days respectively; (d) \& (e) single suspended round isolated cells of somatic embryos with dense cytoplasm. 


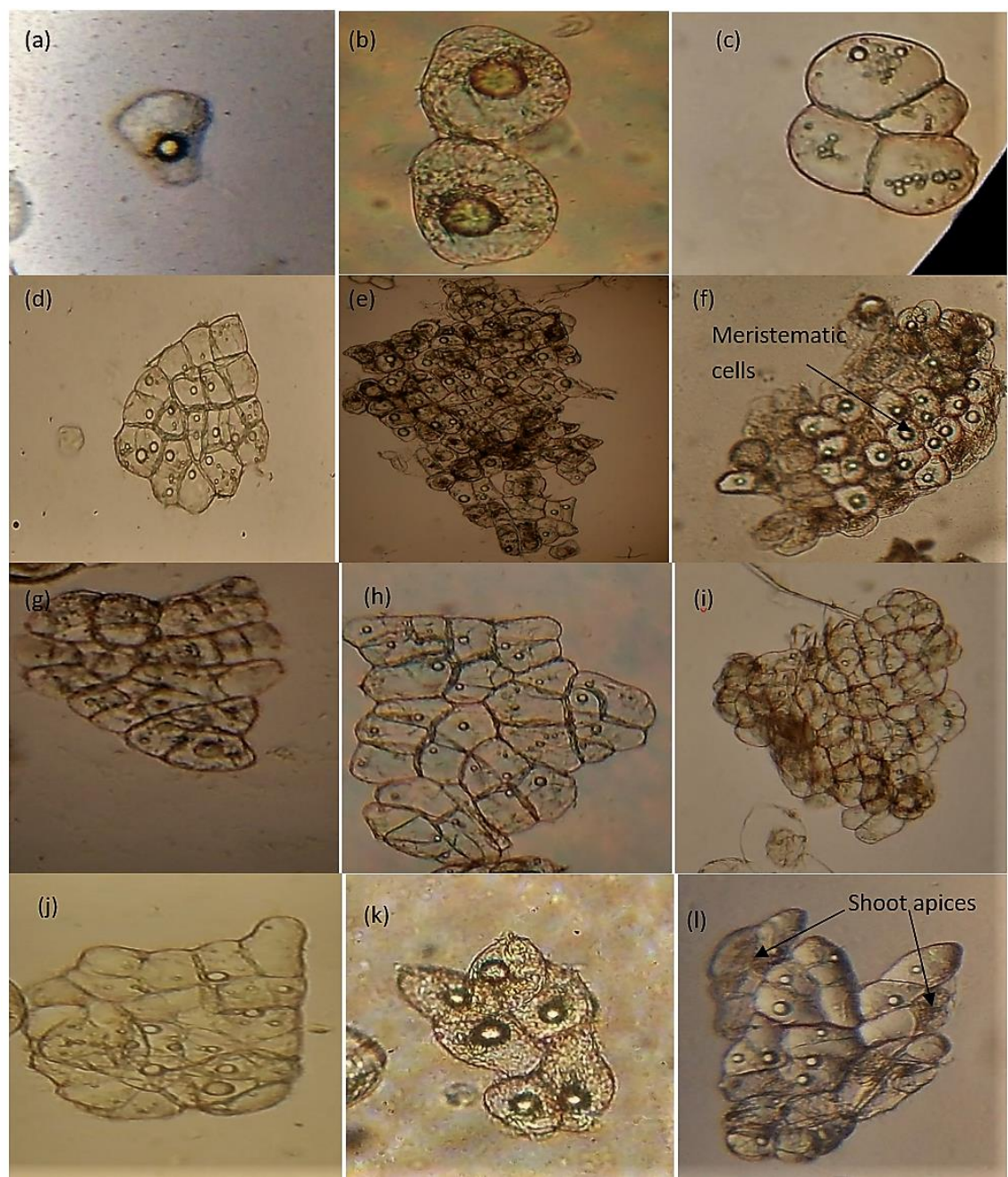

Fig. 3. Light micrographs showing stages in embryo development of G. kurroo suspensions: (a) and (b) Showing a single and pair of cytoplasm-rich somatic cells; (c) 4-celled cytoplasm rich proembryo; (d) a young embryo; (e) and (f) late globular proembryo showing central core of meristematic cells; ( $\mathrm{g}$ ) early heart shaped proembryo; (h) and (i) late heart shaped embryo; (j) and (k) early cotyledonous embryo; (l) late cotyledonous embryo with shoot apices.
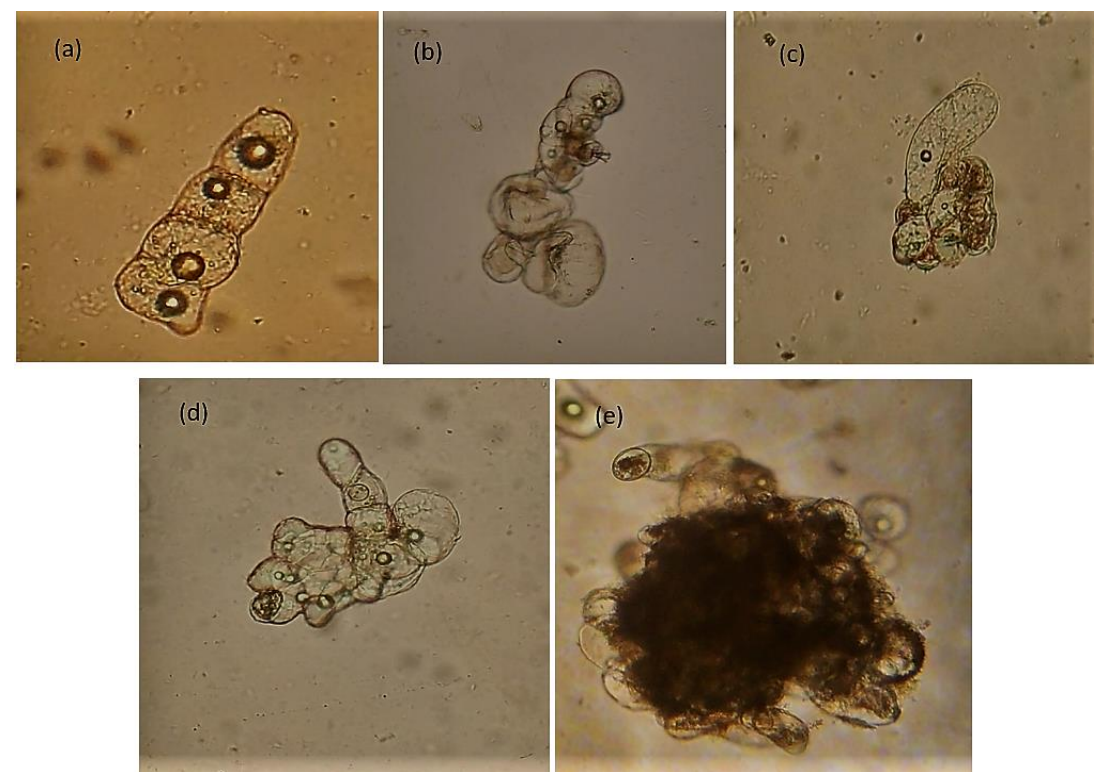

Fig. 4. Different stages of development of embryo from single cell of G. kurroo: (a) Single cell with large vacuolated cells and small richly cytoplasm; (b)-(e) the latter, by a series of divisions, gives rise to a tissue mass from which embryos were differentiated. 


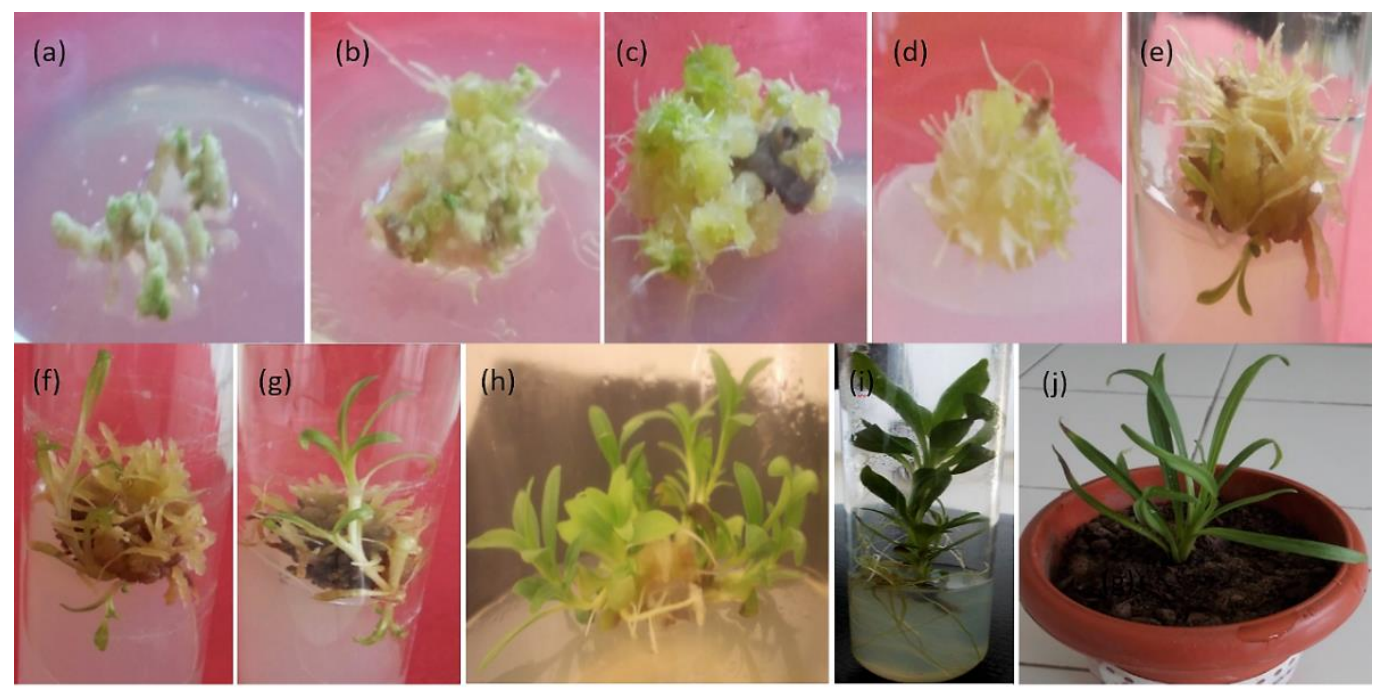

Fig. 5. Plant regeneration through suspension cultures of somatic embryos of G. kurroo:

(a) Large mass of somatic embryo eliminated through suspension culture; (b) sub cultured on 2, 4-D (0.4 mg/l) and KN (1.5 mg/l) after 30 days; (c) fully differentiated somatic embryo after 60 days; (d) somatic embryo subcultured on MS $1 / 2$ strength basal medium after 60 days; (e) and (f) small plantlets generating from somatic embryos after 25 and 35 days respectively; (g) 2- 3 shoots developed after 45 days of culture on MS 1/2 strength basal salts; (h) multiplication of shoots on MS medium supplemented with $0.5 \mathrm{mg} / \mathrm{l}$ each of $\mathrm{KN}$ and BAP after 60 days; (i) root induction on MS $1 / 2$ IBA $(0.5 \mathrm{mg} / \mathrm{l})$ after 4 weeks; (j) 3 months old acclimatized plants grown in greenhouse.

Table 1. Effect of plant growth regulators on initiation of somatic embryogenesis of G. kurroo after 60 days.

\begin{tabular}{|c|c|c|c|c|}
\hline \multirow{2}{*}{$\begin{array}{c}\text { S. No } \\
1 .\end{array}$} & \multicolumn{2}{|c|}{ Growth regulators $(\mathrm{mg} / \mathrm{l})$} & \multirow{2}{*}{$\begin{array}{c}\text { Initiation } \\
\text { time (d) }\end{array}$} & \multirow{2}{*}{$\begin{array}{c}\text { \% Response } \\
-\end{array}$} \\
\hline & & $(0.25)+(0.25)$ & & \\
\hline 2. & & $(0.5)+(0.5)$ & 18 & 58.3 \\
\hline 3. & NAA + TDZ & $(0.75)+(0.75)$ & 15 & 66.6 \\
\hline 4. & & $(1.0)+(1.0)$ & 11 & 83.3 \\
\hline 5. & $\mathrm{NAA}+\mathrm{BAP}+\mathrm{TDZ}$ & $(0.25)+(0.25)+(0.25)$ & 21 & 75 \\
\hline 6. & & $(0.5)+(0.5)+(0.5)$ & 8 & 97.2 \\
\hline 7. & & $(0.5)+(0.25)$ & - & - \\
\hline 8. & 2,4-D + BAP & $(0.75)+(0.5)$ & - & - \\
\hline 9. & & $(1.0)+(0.5)$ & 25 & 33.3 \\
\hline 10. & & $(1.5)+(0.5)$ & 11 & 58.3 \\
\hline 11. & & $(0.25)+(0.25)$ & - & - \\
\hline 12. & $\mathrm{BAP}+\mathrm{TDZ}$ & $(0.5)+(0.5)$ & 21 & 44.4 \\
\hline 13. & & $(0.75)+(0.75)$ & 17 & 69.4 \\
\hline 14. & & $(1.0)+(1.0)$ & 14 & 80.5 \\
\hline 15. & & $(0.25)+(0.25)+(0.25)$ & - & - \\
\hline 16. & 2,4-D + BAP + TDZ & $(0.5)+(0.5)+(0.5)$ & 16 & 75 \\
\hline 17. & & $(0.8)+(0.8)+(0.8)$ & 10 & 83.3 \\
\hline
\end{tabular}

Table 2. Effect of plant growth regulators on the survival percentage of somatic embryogenesis and number of embryos / explants of G. kurroo after 8 weeks.

\begin{tabular}{|c|c|c|c|c|c|}
\hline S.No. & \multicolumn{2}{|c|}{ Growth regulators (mg/l) } & $\begin{array}{c}\text { Initiation time } \\
\text { (days) }\end{array}$ & $\begin{array}{c}\text { *Mean No. of embryos/ } \\
\text { callus piece }\end{array}$ & $\begin{array}{c}\text { Survival Percentage } \\
\text { of S E }(\%)\end{array}$ \\
\hline 1. & \multirow{3}{*}{$\mathrm{NAA}+\mathrm{KN}$} & $0.25+0.25$ & 0.0 & 0.0 & 0.00 \\
\hline 2. & & $0.25+0.75$ & 0.0 & $3.4 \pm 0.09$ & 0.0 \\
\hline 3. & & $0.5+1.0$ & 55 & $6.5 \pm 0.1$ & 5.0 \\
\hline 4. & \multirow{4}{*}{$\mathrm{NAA}+\mathrm{BAP}$} & $0.25+0.25$ & 0.0 & 0.0 & 0.00 \\
\hline 5. & & $0.25+0.75$ & 0.0 & 0.0 & 0.0 \\
\hline 6. & & $0.5+1.0$ & 45 & $13.5 \pm 0.2$ & 15.0 \\
\hline 7. & & $1.0+1.0$ & 50 & $1.9 \pm 0.2$ & 10.0 \\
\hline 8. & \multirow{2}{*}{$\mathrm{BAP}+\mathrm{KN}$} & $1.5+1.0$ & 49 & $7.5 \pm 0.1$ & 25.0 \\
\hline 9. & & $2.0+1.0$ & 33 & $8.9 \pm 0.1$ & 50.0 \\
\hline 10. & \multirow{4}{*}{$\mathrm{IAA}+\mathrm{KN}$} & $1.0+0.25$ & 0.0 & 0.0 & 0.00 \\
\hline 11. & & $1.0+0.5$ & 55 & $7.9 \pm 0.2$ & 5.0 \\
\hline 12. & & $2.0+1.0$ & 44 & $11.6 \pm 0.2$ & 50.0 \\
\hline 13. & & $4.0+2.5$ & 38 & $17.4 \pm 0.1$ & 60.0 \\
\hline 14. & \multirow[t]{2}{*}{ 2,4-D + BAP } & $0.25+1.0$ & 53 & $7.2 \pm 0.2$ & 20 \\
\hline 15. & & $0.4+1.5$ & 35 & $12.8 \pm 0.2$ & 45 \\
\hline 16. & \multirow{2}{*}{$2,4-\mathrm{D}+\mathrm{KN}$} & $0.25+1.0$ & 50 & $12.3 \pm 0.1$ & 55 \\
\hline 17. & & $0.4+1.5$ & 39 & $28.6 \pm 0.2$ & 80 \\
\hline
\end{tabular}

*Each value represents mean \pm SE of 12 replicates per treatment. Results represents the average and standard error of experiments performed in triplicate; ${ }^{* * *} \mathrm{p}<0.05$. 
Table 3. Regeneration frequency of suspension culture for plantlet regeneration after 24 days of culture on a rotary shaker at $110 \mathrm{rpm}$ in dark at $25^{\circ} \mathrm{C} \pm 2^{\circ} \mathrm{C}$

\begin{tabular}{|c|c|c|c|}
\hline S.No. & \multicolumn{2}{|c|}{ Growth regulators $(\mathrm{mg} / \mathrm{l})$} & $\begin{array}{l}\text { Regeneration frequency of suspension } \\
\text { culture on regeneration medium }(\%)\end{array}$ \\
\hline $\begin{array}{l}1 . \\
2 .\end{array}$ & 2, 4-D + BAP & $\begin{array}{l}(0.25)+(0.5) \\
(0.5)+(1.0)\end{array}$ & $\begin{array}{l}46.6 \\
60.0\end{array}$ \\
\hline $\begin{array}{l}3 . \\
4 .\end{array}$ & IAA + BAP & $\begin{array}{l}(0.25)+(0.5) \\
(\mathbf{0 . 5})+(\mathbf{1 . 0 )}\end{array}$ & $\begin{array}{l}40.0 \\
66.6\end{array}$ \\
\hline $\begin{array}{l}5 . \\
6 .\end{array}$ & $2,4-\mathrm{D}+\mathrm{KN}$ & $\begin{array}{l}(0.25)+(0.5) \\
(0.5)+(1.0)\end{array}$ & $\begin{array}{l}26.6 \\
46.6\end{array}$ \\
\hline $\begin{array}{l}7 . \\
8 .\end{array}$ & $\mathbf{I A A}+\mathbf{K N}$ & $\begin{array}{l}(0.25)+(0.5) \\
(0.5)+(1.0)\end{array}$ & $\begin{array}{l}26.6 \\
40.0\end{array}$ \\
\hline $\begin{array}{c}9 . \\
10 .\end{array}$ & NAA + BAP & $\begin{array}{c}(0.25)+(0.5) \\
(0.5)+(1.0)\end{array}$ & $\begin{array}{l}20.0 \\
33.3\end{array}$ \\
\hline
\end{tabular}

Plant regeneration through suspension cultures of somatic embryos.

Individual cotyledonary somatic embryos obtained from cell suspension were cultured on MS medium supplemented with 2, 4-D in combination with BAP and $\mathrm{KN}$. The percentage of somatic embryo survival was $80 \%$ with $28 \pm 0.2$ embryos/ callus piece of 100 $\mu \mathrm{m}$ (Table 3). In 2, 4-D (0.4 mg/l) and KN (1.5 mg/l) supplemented medium, the totipotent calli regenerated into plantlets within 39 days of culture; while 2, 4-D (0.4 mg/l) and BAP (1.5 mg/l) supplemented medium took 35 days for regeneration (Fig. 5a, b). The calli became embryogenic only in the presence of KN. Many reports indicated that in vitro organogenesis required a high cytokinin/ auxin ratio in several plant systems like Eucalyptus grandis, Coffea arabica and Eleusine indica (Luis et al., 1999; Zoriniants et al., 2003; Yemets et al., 2003). In the present study, NAA (0.25- $0.5 \mathrm{mg} / \mathrm{l})$ in combination with BAP and $\mathrm{KN}(0.25-1.0 \mathrm{mg} / \mathrm{l})$ did not find a significant response in survival percentage of somatic embryos $(5 \%$ and $10 \%)$. KN (0.25- $2.5 \mathrm{mg} / \mathrm{l})$ in combination with IAA (1.0- $4.0 \mathrm{mg} / \mathrm{l})$ and BAP (1.0- $2.0 \mathrm{mg} / \mathrm{l}$ ) also elicited a good response with a survival percentage of $50 \%$ and $60 \%$ respectively (Table. 3 ). After 60 days of culture in the 2, 4- D and $\mathrm{KN}$ supplemented MS medium, fully differentiated somatic embryos were formed and were sub cultured on MS $1 / 2$ strength basal medium (Fig. 5 c). It was observed that complete removal of 2, 4-D from the medium favored plant regeneration. Small plantlets were obtained from somatic embryos after $25^{\text {th }}$ day and 2- 3 shoots developed after 45 days of culture (Fig. 5 d-g). 80-90\% somatic embryos developed into complete plants after 6 weeks of culture. Similar study was reported in G. kurroo using seedlings and leaf explants, where, 56-71 \% of somatic embryos developed into germlings and plants, when subcultured in half strength MS medium supplemented without plant growth regulators ((Fiuk and Rybczynski, 2008 c). Many reports indicate that plant development from somatic embryos is usually associated with the elimination of auxin from the medium. Similar studies have been reported by many authors in Astragalus adsurgens, Coffea canephora and Eleusina caracana (Hatanaka et al., 1991; Eapen and George, 1989; Luo and Jia, 1998). Small plantlets were excised from the somatic embryos and inoculated in the MS medium supplemented with 0.5 $\mathrm{mg} / \mathrm{l}$ each of $\mathrm{KN}$ and BAP for the shoot proliferation (Fig.5h). Many reports, on propagation of plant species such as Dendrocalamus strictus and Arundinaria callosa indicated that, $\mathrm{KN}$ in combination with BAP was the best plant growth regulator for the shoot multiplication and proliferation (Chowdhury et al., 2004; Devi and Sharma, 2009). For in vitro root induction, well-developed plants were excised and transferred to the half strength MS medium supplemented with various concentrations of NAA $(0.1-0.5 \mathrm{mg} / \mathrm{l}), \mathrm{IBA}(0.1-0.5 \mathrm{mg} / \mathrm{l})$ and IAA (0.1$0.5 \mathrm{mg} / \mathrm{l})$. Out of these three auxins tried, half strength MS + IBA $(0.5 \mathrm{mg} / \mathrm{l})$ showed the best response with an average of 20-25 roots per plant with a length of 7 to $8 \mathrm{~cm}$ (Fig. 5 i). Shoots with welldeveloped roots were transferred to earthen pots containing a mixture of clay loam and farmyard manure $(1: 1 \mathrm{w} / \mathrm{w})$. The rooted plants were hardened and after six weeks of hardening, the plants were transferred to the greenhouse where 70 to $80 \%$ of plantlets are surviving without any somaclonal variations (Fig. 5 j). Findings of this study have shown a high frequency of somatic embryogenesis in G. kurroo and plant regeneration through suspension cultures which opens up vistas for large scale micropropagation of this valuable medicinal plant, vis-à-vis in situ conservation.

\section{Conclusion}

The present study established somatic embryogenesis and plant regeneration from cell suspension cultures of Gentiana kurroo. The protocol described here could be used for somatic hybridization, genetic transformation, isolation of protoplasts and large-scale propagation of G. kurroo which is highly valuable, critically endangered medicinal herb thereby ruling out the dependence on natural stands to fulfill the growing demands for this species. The present investigation opens up vistas for 
large scale micropropagation of this valuable medicinal plant, vis-à-vis in situ conservation.

\section{Acknowledgments}

The authors are grateful to Prof. D R Sharma for the scientific guidance and Shoolini University, Solan for providing the infrastructure and facilities to conduct this research.

\section{References}

1. Aboshama HMS, Somatic embryogenesis proliferation, maturation and germination in Cajanus cajan, World Journal of Agricultural Science, 2011, 7, 86-95.

2. Bach A, Pawłowska B, Somatic embryogenesis in Gentiana pneumonantheL, Acta Biologica Cracoviensia, 2003, 45, 79-86.

3. Chowdhury P, Das M, Sikdar SR, Pal A, Influence of the physiological age and position of the nodal explants on micropropagation of field-grown Dendrocalamus strictus, Plant Cell Biotechnology and Molecular Biology, 2004, 5, 45-50.

4. Devi WS, Sharma GJ, In vitro propagation of Arundinaria callosa Munro-an edible bamboo from nodal explants of mature plants, Open Plant Science Journal, 2009, 3, 35-39.

5. Eapen S, George L, High frequency plant regeneration through somatic embryogenesis in finger millet (Eleusina carcana Gaertn), Plant Science, 1989, 61, 127-130.

6. Fiuk A, Rajkiewicz M, Rybczynski JJ, In vitro culture of Gentiana kurroo (Royle). Biotechnologia, 2003, 3, 267-274.

7. Fiuk A, Rybczynski JJ, The effect of several factors on somatic embryogenesis and plant regeneration in protoplast cultures of Gentiana kurroo (Royle), Plant Cell Tissue and Organ Culture, 2007, 91, 263-271.

8. Fiuk A, Rybczynski JJ, Factors influencing efficiency of somatic embryogenesis of Gentiana kurroo (Royle) suspension, Plant Biotechnology Reports, 2008 a, 1, 33-39.

9. Fiuk A, Rybczynski JJ, Genotype and plant growth regulator dependent response of somatic embryogenesis from Gentiana spp. leaf explants, In Vitro Cellular and Developmental Biology, 2008 b, 44, 90-99.

10. Fiuk A, Rybczynski JJ, Morphogenic capability of Gentiana kurroo Royle seedling and leaf explants, Acta Physiologiae Plantarum, 2008 c, 30, 157-166.
11. Hatanaka T, Arakawa O, Yasuda T, Uchida N, Yamaguchi T, Effect of plant growth regulators on somatic embryogenesis in leaf culture of Coffea canephora, Plant Cell Reports, 1991, 10, 179-182.

12. Kaushal S, Sidana A, Dev K, In vitro plant production through apical meristem culture of Gentiana kurroo Royle, Journal of Medicinal Plants Studies, 2014, 3, 04-09.

13. Luis PBC, Adriane CMGM, Silvica BRCC, Ana Christina MB, Plant regeneration from seedlings explants of Eucalyptus grandisEurophylla, Plant Cell Tissue and Organ Culture, 1999, 56, 17-23.

14. Luo JP, Jia JF, Callus induction and plant regeneration from hypocotyl explants of the forage legume Astragalus adsurgens, Plant Cell Reports, 1998, 17, 567-570.

15. Mikuła A, Tykarska T, Kuras M, Iwanowska A, Rybczynski JJ, Studies on the morphogenic potential of Gentians in cell suspension, In: Beitrage zur Zuchtungsforschung, Symposium Breeding Research on Medicinal and Aromatic Plants, Quedlinburg, Germany, 1996, 290-295.

16. Mikuła A, Rybczynski JJ, Somatic embryogenesis of Gentiana genus I, the effect of the preculture treatment and primary explant origin on somatic embryogenesis of Gentiana cruciata (L.), G. pannonica (Scop.), and G. tibetica (King), Acta. Physiologiae Plantarum, 2001, 23, 15-25.

17. Mikuła A, Rybczynski JJ, Skierski J, Latkowska MJ, Fiuk A, Somatic embryogenesis of Gentiana genus IV, characterization of Gentiana cruciata and Gentiana tibetica embryogenic cell suspensions, In: Hvoslef-Eide, A K, Preil W, (Eds), Liquid culture systems for plant propagation: Springer, Dordrecht, 2005, 345358.

18. Murashige, T, Skoog F, A revised medium for rapid growth and bioassays with tobacco tissue culture, Physiologia Plantarum, 1962, 15, 473 497.

19. Nagesh KS, Shanthamma C, Pullaiah T, Somatic embryogenesis and plant regeneration from callus cultures of Curculigo orchioides Gaertn, Indian Journal of Biotechnology, 2010, 9, 408.413 .

20. Raina R, Behera MC, Chand R, Sharma Y, Reproductive Biology of Gentiana kurroo Royle, Current Science, 2003, 85, 667-670. 
21. Sharma N, Chandel KPS, Paul A, In vitro propagation of Gentiana kurroo - an indigenous threatened plant of medicinal importance, Plant Cell Tissue and Organ Culture, 1993, 34, 307309.

22. Sharma A, Kaur R, Sharma $\mathrm{N}$, In vitro morphogenic response of different explants of Gentiana kurroo Royle from Western Himalayasan endangered medicinal plant, Physiology and Molecular Biology of Plants, 2014, 20,249-256.

23. Tiwari V, Singh BD, Tiwari NK, Shoot regeneration and somatic embryogenesis from different explants of Brahmi (Bacopa monnieri), Plant Cell Reports, 1998, 17, 538-543.

24. Yemets AI, Klimkina LAA, Tarassenko LV, Blume YB, Efficient callus formation and plant regeneration of goosegrass (Eleusine indica), Plant Cell Reports, 2003, 21, 503-510.

25. Zoriniants SE, Nosov AV, Gonzalez MM, Zeel MM, Vargas VML, Variation of nuclear DNA content during somatic embryogenesis and plant regeneration of Coffea arabica using cytophotometry, Plant Science, 2003, 164, 141 146.

\section{Cite this article as:}

Shiwani Kaushal and Arushdeep Sidana. Somatic embryogenesis and plant regeneration from cell suspension cultures of Gentiana kurroo Royle. Annals of Plant Sciences 7.5 (2018) pp. 22392246.

do http://dx.doi.org/10.21746/aps.2018.7.5.6

Source of support: Shoolini University, Himachal Pradesh, India.

Conflict of interest: Nil 